\title{
Analisis Kinerja Karyawan dan Faktor-Faktor yang Memengaruhinya: Studi Kasus di PT X
}

\begin{tabular}{ccc} 
William Widjaja & \\
& Universitas Pradita \\
e-mail: william.widjaja@ pradita.ac.id & \\
& \\
\hline Diterima & Direvisi & Disetujui \\
$02-12-2021$ & $10-01-2021$ & $11-01-2021$ \\
\hline
\end{tabular}

\begin{abstract}
Abstrak - Berkompetisi di era globalisasi merupakan tantangan tersendiri bagi perusahaan di dalam mengelola sumber daya manusianya agar sumber daya yang dimiliki dapat memberikan kinerja yang maksimal untuk perusahaannya. Penelitian ini berangkat dari adanya gap yang terjadi pada penelitian terdahulu mengenai faktorfaktor yang memengaruhi kinerja karyawan baik itu faktor kompensasi langsung maupun motivasi. Penelitian ini bertujuan untuk menganalisis bagaimana pengaruh kompensasi langsung dan motivasi memengaruhi kinerja karyawan di PT X. Penelitian ini merupakan jenis penelitian survei dengan pendekatan kuantitatif yang menggunakan kuesioner sebagai instrumen untuk mengumpulkan data. Teknik sampling yang digunakan adalah non probability sampling dengan metode sampling jenuh. Teknik analisis yang digunakan untuk mengolah data adalah uji kualitas instrumen yang terdiri dari uji validitas dan reliabilitas, uji asumsi klasik, uji hipotesis (uji t dan f) serta uji regresi linear berganda. Hasil uji statistik menunjukkan bahwa terdapat pengaruh yang signifikan antara kompensasi langsung dan motivasi terhadap kinerja baik secara parsial maupun simultan.
\end{abstract}

Kata Kunci: kinerja karyawan, kompensasi langsung, motivasi.

Abstract-Competing in the globalization era is challenging for many companies to organize their human resource so that they could encourage their employee to give the best performance. This study comes up from the gaps that occurred in previous studies regarding the factors that influence employee performance which is direct compensation and motivation. This study aims to analyze how the direct compensation and motivation impact the employee's performance at PT X. This is a survey research with a quantitative approach using a questionnaire as an instrument to collect the data. The sampling technique used is non probability sampling with a saturated sampling method. The analysis techniques used to process the data are validity tests, reliability tests, classical assumption tests, hypothesis testing ( $t$ and $f$ tests) and multiple linear regression. The results of statistical tests show that there is a significant influence between direct compensation and motivation on performance either partially or simultaneously.

Keywords: employee performance, direct compensation, motivation 


\section{PENDAHULUAN}

Era globalisasi telah membuat persaingan bisnis semakin ketat. Agar mampu bersaing, tidak sedikit perusahaan yang mulai menaruh perhatiannya terhadap pengembangan kualitas SDM (sumber daya manusia) yang dimilikinya. Hal ini dilakukan agar SDM dapat menjadi suatu asset yang diharapkan mampu mendorong pertumbuhan dan kinerja organisasi sehingga mampu menghasilkan (generate) profit yang maksimal bagi perusahaan. Vosloban (2012) menjelaskan bahwa kinerja para karyawan dalam suatu perusahaan memberikan kontribusi yang sangat signifikan terhadap kinerja perusahaannya. Fenomena ini membuat peran divisi HRD (human resource development) pada suatu perusahaan menjadi sangat penting. HRD dalam sebuah perusahaan menjalankan berbagai fungsi salah satunya yang cukup krusial adalah fungsi kompensasi. Kompensasi yang menarik tentunya akan menjadi daya tarik tersendiri bagi pencari kerja (job seeker) untuk menentukan dimana mereka ingin berkarir. Kompensasi yang menarik juga menjadikan perusahaan mampu bersaing di dalam merekrut SDM terbaik yang ada di dalam bursa kerja karena diharapkan dengan masuknya SDM terbaik akan memberikan dampak positif terhadap kinerja karyawan tersebut sehingga memberikan kontribusi positif bagi kinerja perusahaan. Akter \& Hussain (2016) menjelaskan bahwa karyawan akan memberikan usaha yang terbaik di dalam menjalankan pekerjaannya ketika sistem atau skema kompensasi yang diberikan perusahaan sesuai dengan standar yang ada. Begitupun dengan Sudiardhita et al. (2018) juga menjelaskan bahwa semakin baik kompensasi yang diberikan maka semakin tinggi kinerja yang diberikan oleh karyawan terhadap perusahaannya. Namun berbeda dengan Rizal, Idrus, \& Mintarti (2014) yang menyampaikan bahwa kompensasi tidak memiliki pengaruh yang signifikan terhadap kinerja karyawan. Hal ini dapat terjadi jika sistem kompensasi yang diterapkan perusahaan dirasa tidak memenuhi harapan karyawan atau bukan berbasis kinerja melainkan sistem kompensasi yang berbasis jabatan atau pekerjaan. Berdasarkan penjabaran tersebut maka dapat disimpulkan terjadi gap antara penelitian-penelitian sebelumnya terkait dengan pengaruh kompensasi terhadap kinerja karyawan. Mathis \& Jackson (2012) menjelaskan bahwa kompensasi dibagi menjadi dua jenis yaitu kompensasi langsung dan tidak langsung yang mana, kompensasi langsung terdiri dari upah, gaji, bonus, insentif dan opsi saham sedangkan kompensasi tidak langsung terdiri dari asuransi kesehatan dan jiwa, tunjangan cuti dan dana pensiun.

Selain aspek kompensasi yang diberikan perusahaan terhadap karyawannya, faktor motivasi juga merupakan faktor lain yang dapat memacu kinerja dan semangat kerja para karyawan. Memiliki karyawan yang bermotivasi tinggi merupakan hal yang sangat penting bagi sebuah orginasasi di dalam upaya mencapai tujuannya (Said, Zaidee, Zahari, Ali, \& Salleh, 2015). Apabila seorang karyawan merasa termotivasi dalam menjalankan pekerjaannya maka karyawan tersebut akan memiliki etos kerja yang tinggi dan memiliki dedikasi yang tinggi pada kemajuan perusahaan (Ghaffari, Burgoyne, \& Nazri, 2017). Motivasi kerja juga akan memberikan dampak positif lainnya terhadap organisasi dimana karyawan akan memberikan usaha terbaikknya sehingga dapat meminimalisir konflik dalam organisasi, efisiensi sumber daya, tingkat turn over dan absensi yang rendah menghasilkan serta menciptakan hormonisasi serta persatuan di dalam organisasi atau perusahaan (Onanda, 2015). Namun, berbeda dengan Luhur (2014) yang menjelaskan bahwa motivasi kerja tidak memengaruhi kinerja perusahaan, hal ini dapat terjadi jika karyawan telah memiliki persepsi yang kurang baik terhadap suatu proses bisnis internal yang dilakukan oleh perusahaan terhadap karyawannya. Dari penjabaran tersebut maka, dapat disimpulkan terdapat gap penelitian sebelumnya antara motivasi kerja terhadap kinerja karyawan.

Menyadari pentingnya kompensasi dan motivasi terhadap perusahaan, peneliti tertarik untuk meneliti lebih dalam mengenai proses pemberian kompensasi dan motivasi terhadap kinerja karyawannya di PT X. PT X merupakan perusahaan yang berkecimpung dalam bidang webhosting yang mencangkup domain name, shared hosting, VPS, colocation server, dedicated server dan manage server. Pada tahun 2004 PT X berhasil mendapatkan predikat sebagai perusahaan webhosting nomor $1 \mathrm{di}$ Indonesia. Penelitian yang akan dilakukan pada PT X difokuskan pada problematika kompensasi langsung khususnya pada komponen gaji dan insentif. Hal ini disebabkan selain komponen tersebut, tidak diberlakukan di PT X. Selain kompensasi langsung, problematika motivasi yang ada pada diri karyawan di PT X juga akan ditelaah lebih lanjut dan bagaimana pengaruhnya terhadap kinerja. Disamping itu, penelitian ini juga akan melengkapi dan mengisi adanya gap antara penelitian-penelitian sebelumnya serta memberikan pandangan (point of view) yang berbeda terutama di perusahaan-perusahaan yang berbasis layanan webhosting. Oleh karena itu, tujuan dari penelitian ini adalah untuk menganalisis bagaimana pengaruh kompensasi langsung dan motivasi terhadap kinerja karyawan yang terjadi di PT X.

Kinerja karyawan pada umumnya merupakan tolak ukur yang digunakan oleh perusahaan di dalam melakukan penilaian terhadap karyawannya. Karyawan yang memiliki kinerja sesuai dengan standar atau bahkan melebihinya dapat diberikan penghargaan atau sebaliknya, bagi yang belum dapat mencapai standar yang ditentukan dapat dikenakan 
konsekuensi. Bentuk-bentuk penghargaan dan konsekuensi dapat berupa promosi jabatan, kenaikan kompensasi, mutasi, hingga pemberhentian kerja. Melalui proses penilaian kinerja perusahaan juga dapat mengetahui sudah sejauh mana tujuannya tercapai. Menurut Mangkunegara (2013) menjelaskan bahwa kinerja adalah hasil kerja secara kualitas dan kuantitas yang dicapai oleh seorang karyawan dalam melaksanakan tugas dan tanggung jawab yang diberikan kepadanya. Bangun (2012) mendefinisikan kinerja sebagai hasil pekerjaan yang dicapai seseorang berdasarkan persyaratanpersyaratan tertentu untuk dapat dilakukan dalam mencapai tujuan yang disebut juga sebagai standar pekerjaan. Bangun (2012) juga menjelaskan bahwa kinerja seorang karyawan dapat diukur melalui jumlah pekerjaan yang dihasilkan, kualitas pekerjaannya, ketepatan waktu di dalam menyelesaikan pekerjaan, tingkat kehadiran, dan kemampuan di dalam bekerjasama.

Terdapat beberapa penelitian sebelumnya yang membahas bagaimana kinerja seorang karyawan dapat ditingkatkan. Marliani, Parengkuan, \& Lengkong (2016) melakukan penelitian yang bertujuan untuk menganalisis pengaruh kompensasi finansial langsung, finansial tidak langsung dan non finansial terhadap kinerja karyawan. Hasil penelitian menunjukkan bahwa kompensasi finansial langsung dan tidak langsung berpengaruh terhadap kinerja namun tidak dengan kompensasi non finansial sedangkan, secara bersama-sama ketiga variabel terikat dapat memengaruhi kinerja karyawan. Zulkarnaen \& Herlina (2018) melakukan penelitian yang bertujuan untuk menganalisis bagaiamana pengaruh kompensasi langsung dan tidak langsung terhadap kinerja karyawan di PT Pranata Jaya Abadi. Hasil penelitian menunjukkan bahwa kompensasi langsung dan tidak langsung dapat berpengaruh positif dan signifikan terhadap kinerja karyawan baik secara parsial maupun simultan. Hal ini disebabkan karena kompensasi langsung dalam bentuk yang bonus terhadap karyawannya telah memberikan motivasi karyawan untuk memberikan kinerja yang baik. Sejalan dengan penelitian terdahulu, Lestari, Haryono, Kurnia, \& Rda (2020) juga menjelaskan bahwa terdapat pengaruh positif dan signifikan antara antara kompensasi langsung terhadap kinerja karyawan. Oleh karena itu, berdasarkan fakta empiris yang ada maka, patut diduga bahwa terdapat pengaruh yang signifikan secara simultan antara kompensasi langsung dan motivasi terhadap kinerja karyawan di PT X.

Kompensasi langsung merupakan kompensasi yang dibayarkan secara langsung baik dalam bentuk gaji pokok ataupun insentif berbasis kinerja (Bangun, 2012). Hasibuan menjelaskan bahwa kompensasi langsung merupakan gaji, upah dan insentif yang dibayarkan kepada karyawan atas kerja yang dihasilkan. Sejalan dengan hal tersebut Subekhi dan
Jauhar (2012) mengatakan bahwa kompensasi langsung merupakan penghargaan dalam bentuk moneter yang diberikan terhadap karyawan atas kerja yang telah diselesaikan. Berdasarkan beberapa definisi tersebut maka, dapat disimpulkan bahwa kompensasi langsung merupakan imbalan yang diberikan perusahaan dalam bentuk moneter (finansial) baik itu gaji, upah, bonus, insentif atau sejenisnya atas hasil kerja yang telah diberikan oleh karyawan. Mathis dan Jackson (2012) menjelaskan bahwa kompensasi langsung dapat diukur dengan upah, gaji, bonus, insentif dan opsi saham. Pada penelitian ini, peneliti akan menggunakan indikator gaji dan insentif sebagai tolak ukur kompensasi langsung dikarenakan komponen lain tidak diterapkan di PT X.

Terdapat beberapa penelitian terdahulu yang membahas bagaimana kompensasi langsung dapat meningkatkan kinerja seorang karyawan. Putra, Bagia, \& Suwendra (2017) melalui penelitiannya yang berjudul pengaruh kompensasi dan kepuasan kerja terhadap kinerja karyawan menunjukkan hasil bahwa kompensasi langsung memiliki pengaruh yang signifikan terhadap kinerja karyawan. Musyafi, Utami, \& Mayowan (2016) melakukan penelitian yang bertujuan untuk menganalisis pengaruh kompensasi finansial dan non finansial terhadap kinerja karyawan di PT PLN Malang. Hasil penelitian menunjukkan bahwa terdapat pengaruh yang signifikan antara kedua variabel bebas terhadap kinerja secara parsial. Sejalan dengan peneliti terdahulu, Fauziah, Sunurharyo, \& Utami (2016) melakukan penelitian yang bertujuan untuk menganalisis bagaimana pengaruh kompensasi langsung dan tidak langsung terhadap motivasi dan kinerja karyawan. Hasil penelitian menunjukkan bahwa kompensasi langsung memiliki pengaruh yang signifikan terhadap kinerja karyawan. Hal ini disebabkan perusahaan telah memberikan kompensasi langsung seperti ketepatan waktu gaji, besaran gaji, dan bonus dengan baik dan adil sehingga berdampak langsung terhadap kinerja yang diberikan oleh karyawan terhadap perusahaan. Berdasarkan fakta empiris yang ada maka, patut diduga bahwa terdapat pengaruh yang signifikan antara kompensasi langsung terhadap kinerja karyawan di PT X.

Motivasi merupakan suatu kondisi yang mendorong orang lain untuk dapat melaksanakan tugas-tugas sesuai dengan fungsinya dalam organisasi (Bangun, 2012:312). Fahmi (2013) menjelaskan bahwa motivasi merupakan aktivitas perilaku dari seseorang dalam bekerja dalam rangka usaha memenuhi kebutuhan-kebutuhan yang diinginkan. Motivasi juga dapat didefinisikan sebagai suatu stimulasi keinginan (want) dan daya penggerak kemauan bekerja seseorang yang mana setiap motif mempunyai tujuan tertentu yang ingin dicapai (Hasibuan, 2014). Badeni (2013) mendefinisikan motivasi sebagai sesuatu proses yang menghasilkan 
suatu intensitas, arah atau tujuan, dan ketekunan individual dalam mencapai tujuan. Motivasi juga diartikan sebagai proses yang menjelaskan mengenai kekuatan, arah, dan ketekunan seseorang dalam upaya untuk mencapai tujuan (Robbins dan Judge, 2015:127).

Priansa (2016) menjelaskan bahwa motivasi dapat dibagi menjadi dua yaitu motivasi intrinsik dan ekstrinsik. Dimana motivasi intrinsik dapat diukur dari minat, sikap positif dan kebutuhan. Dalam konteks ini, minat merupakan rasa ketertarikan akan melakukan suatu kegiatan, karyawan akan termotivasi untuk mengerjakan sesuatu jika itu merupakan minatnya. Sikap positif merupakan suatu sikap yang ditunjukkan karyawan terhadap suatu pekerjaan seperti memiliki inisiatif untuk ikut dan terlibat dalam suatu kegiatan dan selalu berupaya semaksimal mungkin untuk menyelesaikan pekerjaan dengan sebaik-baiknya. Sedangkan kebutuhan merupakan melakukan suatu pekerjaan atau aktivitas tertentu dikarenakan adanya dorongan untuk memenuhi kebutuhannya.

Priansa (2016) juga menjelaskan bahwa motvasi ekstrinsik merupakan motivasi yang muncul karena adanya rangsangan dari luar. Terdapat dua faktor utama untuk mengukur motivasi ekstrinsik karyawan dalam sebuah organisasi yaitu motivator dan kesehatan kerja. Dimana motivator berkaitan dengan prestasi kerja, penghargaan, tanggung jawab yang diberikan, kesempatan untuk mengembangkan diri sedangkan kesehatan kerja merupakan kebijakan dan administrasi organisasi yang baik, supervisi yang memadai, kepuasaan akan gaji yang diberikan, kondisi kerja yang mendukung, serta keselamatan kerja.

Rahmawati (2014) melakukan penelitian yang bertujuan untuk menganalisis pengaruh motivasi intrinsik dan ekstrinsik terhadap kinerja karyawan PT Daekhyung Indah Heavy Industry. Hasil penelitian menunjukkan bahwa motivasi intrinsik dan ekstrinsik secara parsial berpengaruh signifikan terhadap kinerja karyawan. Dimana, dimensi pengakuan, hubungan dengan teman kerja, kondisi kerja dan gaji yang diterima merupakan dimensi yang paling berpengaruh. Dharmayati (2015) melakukan penelitian yang bertujuan untuk menganalisis motivasi intrinsik dan ekstrinsik terhadap kinerja karyawan dengan kepuasan kerja sebagai variabel intervening. Hasil penelitian menunjukkan bahwa motivasi intrinsik dan ekstrinsik secara langsung berpengaruh terhadap kinerja karyawan. Sejalan dengan peneliti terdahulu, Ghofur, Syairudin, \& Anshori (2017) melalui hasil penelitiannya yang berjudul pengaruh motivasi intrinsik dan ekstrinsik terhadap kinerja karyawan divisi network operations PT XYZ Surabaya menjelaskan bahwa motivasi intrinsik dan ekstrinsik memiliki pengaruh yang signifikan terhadap kinerja karyawan dan pengaruh yang paling dominan ada pada indikator motivasi ekstrinsik yaitu pengawasan atau supervisi. Berdasarkan fakta empiris yang ada maka, patut diduga bahwa terdapat pengaruh yang signifikan antara motivasi terhadap kinerja karyawan di PT X.

\section{METODE PENELITIAN}

Penelitian ini merupakan jenis penelitian survei dengan pendekatan kuantitatif. Dimana, teknik pengumpulan data menggunakan kuesioner yang berisi butir-butir pernyataan yang mengandung unsur-unsur terkait variabel penelitian yakni kompensasi, motivasi dan kinerja karyawan. Skala pengukuran yang digunakan pada kuesioner adalah skala likert dengan nilai 1 sampai dengan 5.

Responden penelitian ini merupakan para karyawan yang bekerja di PT X yang berjumlah 50 karyawan yang dilakukan pada bulan September hingga Oktober 2019. Dikarenakan jumlah karyawan yang tidak terlalu banyak maka, teknik sampling yang digunakan adalah non-probability sampling dengan metode sampel jenuh yang artinya seluruh populasi akan dijadikan sampel penelitian. Sedangkan teknik analisis yang digunakan pada penelitian ini adalah uji instrumen yang terdiri dari uji validitas dan realibilitas data, uji asumsi klasik yang terdiri dari uji normalitas, uji heterokedastisitas dan multikolinearitas, uji hipotesis serta model yaitu menggunakan uji t, uji f dengan derajat kepercayaan atau level signifikansi $95 \%$ dan regresi linear berganda. Alat analisis yang digunakan adalah SPSS versi 22 yang digunakan untuk pengolahan data.

\section{HASIL DAN PEMBAHASAN}

\section{Analisis Deskriptif}

Analisis deskriptif dalam penelitian ini dilakukan untuk memberikan gambaran secara umum terkait dengan demografi responden mulai dari gender, usia dan tingkat pendidikan. Berikut adalah gambaran umum karyawan di PT X.

Tabel 1. Karateristik Responden

\begin{tabular}{|c|c|c|c|}
\hline Karakteristik & Kategori & Jumlah & Persentase \\
\hline \multirow[t]{2}{*}{ Jenis Kelamin } & Laki-Laki & 26 & $52 \%$ \\
\hline & Perempuan & 24 & $48 \%$ \\
\hline \multicolumn{2}{|r|}{ Jumlah } & 50 & $100 \%$ \\
\hline \multirow[t]{5}{*}{ Usia } & $<20$ tahun & 0 & $0 \%$ \\
\hline & $\begin{array}{l}21-30 \\
\text { tahun }\end{array}$ & 47 & $94 \%$ \\
\hline & $\begin{array}{l}31-40 \\
\text { tahun }\end{array}$ & 3 & $6 \%$ \\
\hline & $\begin{array}{l}41-50 \\
\text { tahun }\end{array}$ & 0 & $0 \%$ \\
\hline & $>50$ tahun & 0 & $0 \%$ \\
\hline \multicolumn{2}{|r|}{ Jumlah } & 50 & $100 \%$ \\
\hline \multirow[t]{4}{*}{ Pendidikan } & SLTP & 0 & $0 \%$ \\
\hline & SLTA & 6 & $12 \%$ \\
\hline & Diploma & 10 & $20 \%$ \\
\hline & Sarjana & 34 & $68 \%$ \\
\hline \multicolumn{2}{|c|}{ Jumlah } & 50 & $100 \%$ \\
\hline \multicolumn{2}{|c|}{ Sumber: data diolah (2020) } & & \\
\hline
\end{tabular}


Tabel 1 menunjukkan bahwa berdasarkan jenis kelamin (gender), karyawan di PT. X didominasi oleh laki-laki yaitu sebesar 52\% dibandingkan perempuan yang hanya sebesar $48 \%$. Dikarenakan perusahaan bergerak pada bidang IT dengan jam kerja shifting maka tenaga kerja laki-laki lebih banyak dibutuhkan dibandingkan tenaga kerja perempuan.

Dari kategori usia, karyawan di PT. X mayoritas berusia 21-30 tahun dengan persentase sebesar 94\%, dan sisanya $6 \%$ berusia 41-50. Ini menunjukkan bahwa karyawan PT X didominasi oleh karyawankaryawan yang berada di usia produktif. Hal tersebut dapat menjadi sebuah potensi yang baik bagi perusahaan mengingat industri IT memiliki karakteristik yang berkembang sangat cepat sehingga perusahaan dituntut untuk selalu mampu berinovasi dan beradaptasi pada perubahan tersebut.

Terakhir, berdasarkan kategori tingkat pendidikan, PT $\mathrm{X}$ memiliki karyawan dengan pendidikan S1 sebesar 68\%, D3 sebesar 20\% dan SMA sederajat sebesar $12 \%$. Berdasarkan data tersebut maka, dapat disimpulkan bahwa sebagian besar karyawan di PT. X didominasi oleh tingkat pendidikan S1. Hal ini, tentunya dapat menjadi faktor pendukung yang menguntungkan bagi perusahaan untuk mengoperasionalisasikan dan mengimplementasikan berbagai strategi perusahaan untuk mencapai visi, misi dan tujuannya.

\section{Uji Instrumen Penelitian Uji Validitas}

Uji validitas dilakukan untuk memastikan bahwa butir-butir pernyataan atau item pada instrumen (kuesioner) mampu mengukur secara akurat variabel penelitian baik itu variabel bebas (kompensasi dan motivasi) maupun terikat (kinerja karyawan). Data dapat dikatakan valid jika nilai $r$ hitung lebih besar dari nilai $\mathrm{r}$ tabel (Sunyoto, 2013). Nilai tabel yang digunakan pada taraf signifikansi 5\% dengan jumlah responden 50 orang adalah 0,279.

Tabel 2. Hasil Uji Validitas Instrumen

\begin{tabular}{|c|c|c|c|}
\hline Variabel & Indikator & Item & $\mathbf{r}_{\text {hitung }}$ \\
\hline \multirow{6}{*}{$\begin{array}{l}\text { Kompensasi } \\
\text { Finansial }\end{array}$} & \multirow[t]{3}{*}{ Gaji } & X11 & 0,393 \\
\hline & & $\mathrm{X} 12$ & 0,481 \\
\hline & & $\mathrm{X} 13$ & 0,551 \\
\hline & \multirow[t]{3}{*}{ Insentif } & $\mathrm{X} 14$ & 0,666 \\
\hline & & $\mathrm{X} 15$ & 0,441 \\
\hline & & $\mathrm{X} 16$ & 0,509 \\
\hline \multirow[t]{6}{*}{ Motivasi } & \multirow[t]{3}{*}{ Intrinsik } & $\mathrm{X} 21$ & 0,945 \\
\hline & & $\mathrm{X} 22$ & 0,929 \\
\hline & & $\mathrm{X} 23$ & 0,945 \\
\hline & \multirow[t]{3}{*}{ Ekstrinsik } & $\mathrm{X} 24$ & 0,499 \\
\hline & & $\mathrm{X} 25$ & 0,885 \\
\hline & & X26 & 0,923 \\
\hline \multirow{7}{*}{$\begin{array}{l}\text { Kinerja } \\
\text { Karyawan }\end{array}$} & \multirow[t]{3}{*}{ Jumlah Pekerjaan } & Y11 & 0,340 \\
\hline & & Y12 & 0,355 \\
\hline & & $\mathrm{Y} 13$ & 0,479 \\
\hline & \multirow{3}{*}{$\begin{array}{l}\text { Kualitas } \\
\text { Pekerjaan }\end{array}$} & Y14 & 0,524 \\
\hline & & Y15 & 0,597 \\
\hline & & Y16 & 0,552 \\
\hline & Ketepatan Waktu & Y17 & 0,557 \\
\hline
\end{tabular}

\begin{tabular}{|l|l|c|c|}
\hline \multirow{4}{*}{} & & Y18 & 0,548 \\
\cline { 3 - 4 } & \multirow{3}{*}{ Kehadiran } & Y19 & 0,606 \\
\cline { 3 - 4 } & & Y110 & 0,489 \\
\cline { 3 - 4 } & & Y112 & 0,565 \\
\cline { 2 - 4 } & Kemampuan & Y113 & 0,600 \\
\cline { 2 - 4 } & \multirow{2}{*}{ Kerjasama } & Y115 & 0,554 \\
\cline { 3 - 4 } & & Y116 & 0,372 \\
\hline
\end{tabular}

Sumber: data diolah (2020)

Tabel 2 menunjukkan bahwa seluruh item atau butir pernyataan memiliki nilai $\mathrm{r}_{\text {hitung }}$ yang lebih besar dibandingkan nilai $r_{\text {tabel }}(0,279)$ maka, dapat disimpulkan bahwa seluruh item pernyataan tersebut dikatakan valid sehingga data dapat digunakan untuk analisis lebih lanjut.

\section{Uji Reliabilitas}

Uji reliabilitas digunakan untuk menguji konsistensi instrumen terhadap variabel yang ingin diukur. Data dapat dikatakan reliabel jika nilai cronbach alpha $(\alpha)$ lebih besar atau sama dengan 0,7 (Supriyadi, 2014). Berikut adalah hasil uji reliabilitas terhadap seluruh butir.

Tabel 3. Hasil Uji Reliabilitas

\begin{tabular}{|l|c|}
\hline \multicolumn{1}{|c|}{ Variabel } & Cronbach Alpha $(\alpha)$ \\
\hline Kompensasi Finansial & 0,762 \\
\hline Motivasi & 0,953 \\
\hline Kinerja Karyawan & 0,851 \\
\hline \multicolumn{2}{|l|}{ Sumber: output IBM SPSS 22 (2020) }
\end{tabular}

Tabel 3 menunjukkan bahwa seluruh seluruh variabel memiliki nilai cronbach alpha $(\alpha)$ di atas 0,7 sehingga dapat disimpulkan bahwa instrumen konsisten di dalam mengukur variabel (reliabel) dan dapat digunakan untuk uji dan analisis lebih lanjut.

\section{Uji Asumsi Klasik Uji Normalitas}

Uji normalitas merupakan uji asumsi yang digunakan untuk menganalisis apakah data yang terkumpul dari sampel berdistribusi normal atau tidak. Pada penelitian ini ukuran normalitas menggunakan uji kolmogorov smirnov yang mana, apabila nilai signifikansi lebih besar dari 0,05 maka data dapat dikatakan berdistribusi normal (Ghozali, 2016). Berikut adalah hasil uji normalitas data dengan uji kolmogorov smirnov.

Tabel 4. Hasil Uji Normalitas

\begin{tabular}{|l|l|r|}
\hline \multicolumn{2}{|c|}{} & $\begin{array}{c}\text { Unstandardized } \\
\text { Residual }\end{array}$ \\
\hline $\mathrm{N}$ & Mean & 50 \\
\hline \multirow{2}{*}{$\begin{array}{l}\text { Normal } \\
\text { Parameters }\end{array}$} & Std. Deviation & .0000000 \\
\hline \multirow{2}{*}{$\begin{array}{l}\text { Most Extreme } \\
\text { Differences }\end{array}$} & Absolute & 4.21742956 \\
\cline { 2 - 3 } & Positive & .079 \\
\cline { 2 - 3 } & Negative & .079 \\
\hline Test Statistic & -.068 \\
\hline Asymp. Sig. (2-tailed) & .079 \\
\hline Sumber: output IBM SPSS 22 (2020) & $.200^{\mathrm{c}, \mathrm{d}}$ \\
\hline
\end{tabular}


Tabel 4 menunjukkan bahwa nilai signifikansi adalah sebesar 0,200 yang mana lebih besar dari 0,5 maka, dapat disimpulkan bahwa data yang terkumpul telah berdistribusi normal dan telah memenuhi syarat asumsi klasik normalitas sehingga data dapat digunakan untuk diuji dan dianalisis lebih lanjut.

\section{Uji Heteroskedastisitas}

Uji heteroskedastisitas merupakan uji yang digunakan untuk menilai ada atau tidaknya ketidaksamaan varian dari residual untuk semua pengamatan pada model regresi linear sehingga model regresi yang baik adalah memiliki kesamaan varian dari error semua pengamatan pada setiap variabel bebas dalam model regresi. Untuk menilai ada atau tidaknya ketidaksamaan varian, peneliti menggunakan uji glejser sebagai tolak ukur. Dimana, apabila nilai signifikansi lebih besar dari 0,05 maka, variabel bebas pada model regresi memiliki kesaamaan varian atau tidak terjadinya heteroskedastisitas (Ghozali, 2016). Hasil uji glejser pada penelitian ini dapat dilihat pada tabel berikut

Tabel 5. Hasil Uji Glejser

\begin{tabular}{|c|c|c|c|c|c|c|}
\hline \multirow{2}{*}{\multicolumn{2}{|c|}{ Model }} & \multicolumn{2}{|c|}{$\begin{array}{l}\text { Unstandardized } \\
\text { Coefficients }\end{array}$} & \multirow{2}{*}{$\begin{array}{c}\text { Standard } \\
\text { ized } \\
\text { Coeffici } \\
\text { ents } \\
\text { Beta }\end{array}$} & \multirow[t]{2}{*}{$\mathrm{t}$} & \multirow[t]{2}{*}{ Sig. } \\
\hline & & $\mathrm{B}$ & Std Frror & & & \\
\hline \multirow[t]{3}{*}{1} & (Constant) & .056 & .059 & & .948 & .348 \\
\hline & $\mathrm{X} 1$ & .003 & .002 & .243 & 1.775 & .082 \\
\hline & $\mathrm{X} 2$ & .004 & .002 & -.248 & -1.814 & .076 \\
\hline \multicolumn{7}{|c|}{$\begin{array}{l}\text { a. Dependent Variable: ABS_RES2 } \\
\text { Sumber: output IBM SPSS } 22(2020)\end{array}$} \\
\hline
\end{tabular}

Tabel 5 menunjukkan bahwa nilai signifikansi masing-masing variabel bebas adalah 0,082 dan 0,076 yang artinya bahwa variabel bebas pada model regresi memiliki kesamaan varian maka, dapat disimpulkan bahwa tidak terjadinya heteroskedastisitas sehingga data dapat digunakan untuk diuji dan dianalisis lebih lanjut.

\section{Uji Multikolinearitas}

Uji multikolinearitas merupakan uji asumsi klasik ketiga yang digunakan pada penelitian ini yang berfungsi untuk memastikan apakah ada interkorelasi antar variabel bebas. Sebuah model regresi yang baik adalah tidak terjadinya multikolinearitas. Model regresi dikatakan tidak terjadi multikolinearitas apabila memiliki nilai tolerance lebih dari 0,1 dan VIF lebih kecil dari 5 (Ghozali, 2016). Hasil uji tolerance dan VIF adalah sebagai berikut:

Tabel 6. Hasil Uji Multikolinearitas

\begin{tabular}{|c|c|c|c|c|c|c|c|c|}
\hline \multirow{2}{*}{\multicolumn{2}{|c|}{ Model }} & \multicolumn{2}{|c|}{$\begin{array}{l}\text { Unstandardized } \\
\text { Coefficients }\end{array}$} & \multirow{2}{*}{$\begin{array}{c}\text { Standardized } \\
\text { Coefficients } \\
\text { Beta } \\
\end{array}$} & \multirow[t]{2}{*}{$\mathrm{t}$} & \multirow[t]{2}{*}{ Sig. } & \multicolumn{2}{|c|}{ Collinearity Statistics } \\
\hline & & B & Std. Error & & & & Tolerance & VIF \\
\hline \multirow[t]{3}{*}{1} & (Constant) & 36.114 & 6.463 & & 5.588 & .000 & & \\
\hline & X1 & .532 & .213 & .325 & 2.494 & .016 & 999 & 1.001 \\
\hline & $\mathrm{X} 2$ & .537 & .215 & .325 & 2.502 & .016 & .999 & 1.001 \\
\hline
\end{tabular}

Tabel 6 menunjukkan bahwa nilai tolerance kedua variabel bebas berada di angka 0,999 sedangkan nilai VIF keduanya sebesar 1,001. Ini menunjukkan bahwa tidak terjadinya interkorelasi antar variabel bebas karena keduanya memiliki nilai tolerance lebih besar dari 0,1 dan nilai VIF lebih kecil dari 5 sehingga data dapat digunakan untuk diuji dan dianalisis lebih lanjut.

\section{Uji Hipotesis \\ Uji F}

Uji F merupakan uji statistik yang digunakan untuk menguji apakah seluruh variabel bebas memiliki pengaruh terhadap variabel terikat secara bersama-sama atau simultan. Tolak ukurnya adalah apabila F hitung lebih besar dari pada nilai $\mathrm{F}$ tabel dan nilai signifikansi lebih kecil atau sama dengan 0,05 maka, dapat simpulkan bahwa variabel bebas secara simultan memengaruhi variabel terikat (Ghozali, 2016). Hasil uji F pada penelitian ini menunjukkan hasil sebagai berikut : 
Tabel 7. Hasil Uji F

\begin{tabular}{|l|l|r|r|r|r|c|}
\hline \multicolumn{2}{|l|}{ Model } & Sum of Squares & df & Mean Square & F & Sig. \\
\hline \multirow{3}{*}{1} & Regression & 224.931 & 2 & 112.466 & 6.065 & $.005^{\text {b }}$ \\
\cline { 2 - 7 } & Residual & 871.549 & 47 & 18.544 & & \\
\cline { 2 - 7 } & Total & 1096.480 & 49 & & & \\
\hline \\
a. Dependent Variable: Y \\
\hline $\begin{array}{l}\text { b. Predictors: (Constant), X2, X1 } \\
\text { Sumber: output IBM SPSS 22 (2020) }\end{array}$ \\
\hline
\end{tabular}

Tabel 7 menunjukkan bahwa nilai $\mathrm{F}$ hitung sebesar 6,065 yang mana nilai ini lebih besar dari $\mathrm{F}$ tabel yaitu 3,210 sedangkan nilai signifikansi menunjukkan nilai sebesar 0,005 yang artinya juga lebih besar dari 0,05. Hal ini menunjukkan bahwa hipotesis alternatif diterima atau dapat disimpulkan bahwa variabel kompensasi langsung dan motivasi secara bersama-sama dapat memengaruhi kinerja karyawan.

\section{Uji T}

Uji T merupakan uji statistik yang digunakan untuk menguji apakah variabel bebas memiliki pengaruh terhadap variabel terikat secara parsial atau masing-masing. Tolak ukurnya adalah apabila $\mathrm{T}$ hitung lebih besar dari pada nilai $\mathrm{T}$ tabel dan nilai signifikansi lebih kecil atau sama dengan 0,05 maka, dapat simpulkan bahwa variabel bebas secara parsial memengaruhi variabel terikat (Ghozali, 2016). Hasil uji T pada penelitian ini menunjukkan hasil sebagai berikut.

Tabel 8. Hasil Uji T

\begin{tabular}{|c|c|c|c|c|c|c|c|c|}
\hline \multirow{2}{*}{\multicolumn{2}{|c|}{ Model }} & \multicolumn{2}{|c|}{$\begin{array}{l}\text { Unstandardized } \\
\text { Coefficients }\end{array}$} & \multirow{2}{*}{$\begin{array}{c}\begin{array}{c}\text { Standardized } \\
\text { Coefficients }\end{array} \\
\text { Beta } \\
\end{array}$} & \multirow[t]{2}{*}{$\mathrm{t}$} & \multirow[t]{2}{*}{ Sig. } & \multicolumn{2}{|c|}{ Collinearity Statistics } \\
\hline & & B & Std. Error & & & & Tolerance & VIF \\
\hline \multirow[t]{3}{*}{1} & (Constant) & 36.114 & 6.463 & & 5.588 & .000 & & \\
\hline & $\mathrm{X} 1$ & .532 & .213 & .325 & 2.494 & .016 & .999 & 1.001 \\
\hline & $\mathrm{X} 2$ & .537 & .215 & .325 & 2.502 & .016 & .999 & 1.001 \\
\hline
\end{tabular}

Tabel 8 menunjukkan bahwa nilai $\mathrm{T}$ hitung variabel x1 (kompensasi langsung) adalah sebesar 2,494 yang mana nilai ini lebih besar dari $\mathrm{T}$ tabel yaitu 1,676 sedangkan nilai signifikansi menunjukkan nilai sebesar 0,016 atau lebih besar dari 0,05 . Hal ini menunjukkan bahwa hipotesis alternatif diterima atau dapat disimpulkan bahwa variabel kompensasi langsung memiliki pengaruh terhadap kinerja karyawan. Disamping itu tabel 1.8 juga menunjukkan bahwa nilai $\mathrm{T}$ hitung variabel $\mathrm{X} 2$ (motivasi) adalah sebesar sebesar 2,502 yang mana nilai ini lebih besar dari T tabel yaitu 1,676 sedangkan nilai signifikansi menunjukkan nilai sebesar 0,016 atau lebih besar dari 0,05. Hal ini menunjukkan bahwa hipotesis alternatif diterima atau dapat disimpulkan bahwa variabel motivasi secara signifikan memiliki pengaruh terhadap kinerja karyawan.

\section{Uji Regresi Linear Berganda}

Berdasarkan uji regresi berganda yang telah dilakukan didapatkan hasil sebagai berikut:
Tabel 9. Hasil Uji Regresi Berganda

\begin{tabular}{|c|l|r|r|c|}
\hline \multicolumn{2}{|c|}{ Model } & \multicolumn{2}{|c|}{$\begin{array}{l}\text { Unstandardized } \\
\text { Coefficients }\end{array}$} & $\begin{array}{c}\text { Standardize } \\
\text { d } \\
\text { Coefficients }\end{array}$ \\
\cline { 2 - 5 } \multicolumn{2}{|c|}{} & \multicolumn{1}{|c|}{ B } & $\begin{array}{c}\text { Std. } \\
\text { Error }\end{array}$ & Beta \\
\hline \multirow{2}{*}{1} & (Constant & 36.11 & 6.46 & \\
& ) & 4 & 3 & \\
\cline { 2 - 5 } & X1 & .532 & .213 & .325 \\
\cline { 2 - 5 } & X2 & .537 & .215 & .325 \\
\hline
\end{tabular}

Sumber: output IBM SPSS 22 (2020)

Merujuk pada tabel 9 maka, persamaan regresi linear berganda pada penelitian ini adalah sebagai berikut:

$\mathrm{Y}=36,114+0,532 \mathrm{X}_{1}+0,537 \mathrm{X}_{2}$

Persamaan tersebut dapat diartikan bahwa, nilai koefisien regresi variabel kompensasi langsung adalah sebesar 0,532 sehingga jika nilai variabel kompensasi langsung mengalami peningkatan 1 poin dan variabel motivasi diasumsikan tetap maka, nilai kinerja karyawan akan meningkat sebesar 0,532. Sedangkan apabila variabel motivasi mengalami peningkatan sebanyak 1 poin dan diasumsikan variabel kompensasi tetap maka, nilai variabel kinerja karyawan akan meningkat sebesar 0,537. Sehingga dapat disimpulkan, semakin tinggi usaha perusahaan meningkatkan usahanya dalam memberikan kompensasi langsung dan motivasi terhadap karyawannya maka, semakin besar pula kinerja karyawan yang didapatkan. 
Pengaruh Kompensasi Langsung dan Motivasi Secara Simultan Terhadap Kinerja Karyawan

Hasil uji simultan menunjukkan nilai Fhit adalah sebesar 6,065 yakni lebih besar dari Ttabel $(3,210)$. Dimana, menunjukkan bahwa terdapat pengaruh positif dan signifikan antara kompensasi langsung dan motivasi secara simultan terhadap kinerja karyawan di PT X. Hal ini dapat disimpulkan bahwa semakin tinggi atau baik kompensasi langsung dan motivasi yang diberikan terhadap karyawan, semakin tinggi juga kinerja yang akan dihasilkan oleh karyawan PT X. Penelitian ini sejalan dan didukung oleh hasil penelitian sebelumnya yang dilakukan oleh Putra et al. (2016); Musyafi et al. (2016); Fauziah et al. (2016); Bharata (2016) yang juga menjelaskan bahwa variabel kompensasi langsung dan motivasi bersama-sama secara signifikan memengaruhi kinerja karyawan

\section{Pengaruh Kompensasi Langsung Terhadap Kinerja Karyawan}

Hasil uji parsial menunjukkan nilai Thit variabel kompensasi langsung adalah sebesar 2,494 yakni lebih besar dari Ttabel (1,676). Dimana, menunjukkan bahwa terdapat pengaruh positif dan signifikan antara kompensasi langsung terhadap kinerja karyawan di PT X. Hal ini dapat disimpulkan bahwa semakin tinggi atau baik kompensasi langsung yang diberikan terhadap karyawan, semakin tinggi juga kinerja yang akan dihasilkan. Penelitian ini sejalan dan didukung oleh hasil penelitian sebelumnya yang dilakukan oleh Subianto (2016); Haeruddin (2017); Ratnasari \& Mahmud (2020) yang juga menjelaskan bahwa indikator dari kompensai langsung yaitu gaji dan insentif memiliki pengaruh yang signifikan terhadap kinerja karyawan.

\section{Pengaruh Motivasi Terhadap Kinerja Karyawan}

Hasil uji parsial menunjukkan nilai Thit variabel motivasi adalah sebesar 2,502 yakni lebih besar dari Ttabel (1,676). Dimana, menunjukkan bahwa terdapat pengaruh positif dan signifikan antara motivasi terhadap kinerja karyawan di PT X. Hal ini dapat disimpulkan bahwa semakin tinggi atau baik motivasi yang diberikan terhadap karyawan, semakin tinggi juga kinerja yang akan dihasilkan. Penelitian ini sejalan dan didukung oleh hasil penelitian terdahulu yang dilakukan oleh Rahmawati (2014); Dharmayati (2015); Ghofur et al. (2017) yang juga menjelaskan bahwa indikator dari motivasi yaitu intrinsik maupun ekstrinsik memiliki pengaruh yang signifikan terhadap kinerja karyawan.

\section{KESIMPULAN}

Berdasarkan hasil analisis dari uji statistik yang telah dilakukan maka penelitian ini dapat disimpulkan menjadi tiga yaitu kompensasi langsung dan motivasi secara simultan berpengaruh signifikan terhadap kinerja karyawan di PT X. Kompensasi langsung yang terdiri dari pemberian gaji dan insentif memiliki pengaruh positif dan signifikan terhadap kinerja karyawan di PT X sehingga perusahaan disarankan agar perusahaan mampu mengaplikasikan sistem penggajian dan insentif yang berbasis kepada kinerja, beban kerja dan standar kebutuhan pokok sehingga karyawan akan merasa diperlakukan adil dan selalu memberikan kinerja atau performa terbaiknya. Motivasi yang terdiri dari motivasi intrisik dan ekstrinsik memiliki pengaruh positif dan signifikan terhadap kinerja karyawan di PT X sehingga perusahaan disarankan agar mampu terus menjaga motivasi karyawan di level tertinggi dengan cara pimpinan memberikan pengakuan atas prestasi kerja yang dicapai bawahannya, mengembangkan potensi yang ada di dalam diri karyawan, serta menciptakan suasana kerja yang positif, kondusif dan harmonis sehingga karyawan dapat termotivasi untuk memberikan kinerja terbaik.

\section{REFERENSI}

Akter, N., \& Hussain, M. M. (2016). Effect of Compensation on Job Performance: An Empirical Study. International Journal of Engineering Technology, Management and Applied Sciences, 4(August 2016), 315-324. https://doi.org/10.1007/978-3-030-49889-4_26

Badeni. (2013). Kepemimpinan dan Perilaku Organisasi. Bandung: Alfabeta.

Bangun, W. (2012). Manajemen Sumber Daya Manusia. Jakarta: Erlangga.

Bharata, A. (2016). The Influence of Compensation and Training toward Work Discipline and Its Impact on the Employees' Performance in the Research Center of Science and Technology (PUSPIPTEK). The Winners, 17(1), 1. https://doi.org/10.21512/tw.v17i1.1803

Dharmayati, A. (2015). Pengaruh Motivasi Intrinsik Dan Ekstrinsik Terhadap Kinerja Karyawan Dengan Kepuasan Kerja Sebagai Variabel Intervening Di Badan Pusat Statistik Provinsi Daerah Istimewa Yogyakarta. Jurnal Manajemen Bisnis, 6(2), 429-450.

Fahmi, I. (2013). Perilaku Organisasi, Teori, Aplikasi, dan Kasus. Jakarta: Alfabeta.

Fauziah, S., Sunurharyo, B. S., \& Utami, H. N. (2016). KARYAWAN ( Studi pada AJB Bumiputera 1912 Cabang Celaket Malang ). Jurnal Administrasi Bisnis, 37(1), 178-187. Retrieved

from https://media.neliti.com/media/publications/87 175-ID-pengaruh-kompensasi-langsung-dankompens.pdf

Ghaffari, S., Burgoyne, J., \& Nazri, M. (2017). The Influence of Motivation on Job Performance: A Case Study at Universiti Teknologi Malaysia. Australian Journal of Basic and Applied Sciences, 4(March), 92-99.

Ghofur, M. A., Syairudin, B., \& Anshori, M. Y. (2017). Pengaruh Motivasi Intrinsik dan 
Ekstrinsik Terhadap Kinerja Karyawan Divisi Network Operations PT XYZ Surabaya. Business and Finance Journal, 2(1), 45-60. https://doi.org/10.33086/bfj.v2i1.465

Ghozali, I. (2016). Aplikasi Analisis Multivariate dengan Program IBM SPSS 23. Semarang : Universitas Diponegoro.

Haeruddin, M. I. M. (2017). Pengaruh Gaji dan Insentif terhadap Kinerja Karyawan dan Organisational Citizenship Behaviour ( OCB ) pada Hotel Grand Clarion di Makassar. Aplikasi Manajemen Ekonomi Dan Bisnis, 2(1), 11-21.

Hasibuan, H. M. (2014). Manajemen Sumber Daya Manusia. Jakarta: Bumi Aksara.

Lestari, F., Haryono, S., Kurnia, M., \& Rda, P. (2020). The Effect of Direct Compensation and Indirect Compensation on Job Performance with Job Satisfaction as Intervening Variable in Performance of Temporary Staff Umy. Www.Ijbmm.Com International Journal of Business Marketing and Management, 5(3), 2456-4559. Retrieved from www.ijbmm.com

Luhur, Y. (2014). Pengaruh Kepemimpinan, Motivasi Kerja Dan Lingkungan Kerja Terhadap Kinerja Karyawan Pada Biro Pengawasan Dan Pemeriksaan Pt Bank Panin Tbk. Journal of Chemical Information and Modeling, 53(9), 1689-1699.

Mangkunegara, A. P. (2013). Manajemen Sumber Daya Manusia Perusahaan. Bandung: Remaja Rosdakarya.

Marliani, M., Parengkuan, T., \& Lengkong, V. (2016). ISSN 2303-1174 M.D. Marliani., T. Parengkuan., V.P.K. Lengkong. Pengaruh Kompensasi .... Jurnal EMBA, 4(4), 1108 1117.

Mathis, R. L., \& Jackson, J. H. (2012). Manajemen Sumber Daya Manusia. Jakarta: Salemba Empat.

Musyafi, R., Utami, H. N., \& Mayowan, Y. (2016). Pengaruh Kompensasi Finansial dan Non Finansial Terhadap Kinerja Karyawan ( Studi pada Karyawan PT PLN ( Persero ) Area Pelayanan dan Jaringan ( APJ ) Malang ). Jurnal Administrasi Bisnis(JAB), 39(2), 149157.

Onanda, B. (2015). The Effects of Motivation on Job Performance A Case Study of KCB Coast Region. International Journal of Scientific and Research Publications, 5(1), 2250-3153. Retrieved from www.ijsrp.org

Priansa, D. J. (2016). Perencanaan dan Pengembangan SDM. Bandung: Alfabeta.

Putra, I. B. A. K., Bagia, I. W., \& Suwendra, I. W. (2017). Pengaruh Kompensasi Dan Kepuasan Kerja Terhadap Kinerja Karyawan. Jurnal Bisnis Darmajaya, 3(1), 1-13.

Rahmawati, I. (2014). Pengaruh Motivasi Intrinsik
Dan Motivasi Ekstrinsik Terhadap Kinerja Karyawan Pt. Daekyung Indah Heavy Industry. Jurnal OE, VI(2), 152-163.

Ratnasari, I., \& Mahmud, A. (2020). Pengaruh Gaji dan Insentif terhadap Kinerja Karyawan Bagian Produksi PT. Uniplastindo Interbuana Pandaan. Jurnal Aplikasi Manajemen Dan Inovasi Bisnis, 2(2), 66-79. Retrieved from http://garuda.ristekbrin.go.id/documents/detail/ 1665378

Rizal, M., Idrus, M. S., \& Mintarti, R. (2014). Effect of Compensation on Motivation , Organizational Commitment and Employee Performance ( Studies at Local Revenue Management in Kendari City ). International Journal of Business and Management Invention, 3(2), 64-79.

Robbins, \& Judge. (2015). Perilaku Organisasi Edisi 16 (Alih Bahasa Ratna Saraswati dan Febriella Sirait). Jakarta: Salemba Empat.

Said, N. S. M., Zaidee, A. S. A. E., Zahari, A. S. M., Ali, S. R. O., \& Salleh, S. M. (2015). Relationship between employee motivation and job performance: A study at universiti teknologi MARA (Terengganu). Mediterranean Journal of Social Sciences, 6(4S2), 632-638. https://doi.org/10.5901/mjss.2015.v6n4s2p632

Subekhi, A., \& Jauhari, M. (2012). Pengantar Manajemen Sumber Daya Manusia. Jakarta: Prestasi Pustaka.

Subianto, M. (2016). Pengaruh Gaji Dan Insentif Terhadap Kinerja Karyawan Pada Pt . Serba Mulia Auto. EJournal Adminsitrasi Bisnis, 4, 698-712.

Sudiardhita, K. I. R., Mukhtar, S., Hartono, B., Herlitah, Sariwulan, T., \& Nikensari, S. I. (2018). The effect of compensation, motivation of employee and work satisfaction to employee performance PT. Bank XYZ (Persero) Tbk. Academy of Strategic Management Journal, 17(4), 1-14.

Sunyoto, D. (2013). Metodologi Penelitian Akuntansi. Bandung: Refika Aditama.

Supriyadi, E. (2014). SPSS + AMOS. Jakarta: In Media.

Vosloban, R. I. (2012). The Influence of the Employee's Performance on the Company's Growth - A Managerial Perspective. Procedia Economics and Finance, 3(12), 660-665. https://doi.org/10.1016/s2212-5671(12)002110

Zulkarnaen, W., \& Herlina, R. (2018). Pengaruh Kompensasi Langsung dan Kompensasi Tidak Langsung Terhadap Kinerja Karyawan Bagian Staff Operasional PT Pranata Jaya Abadi Banjaran. Jurnal Ilmiah Manajemen Ekonomi Dan Akuntansi, 2(2), 90-114. 